\title{
Traditional Railway Games on Physical Education and Sports Learning with a Teaching Personal and Social Responsibility Approach of Lower Graders at Elementary School
}

\author{
Hermawan Pamot Raharjo ${ }^{1}$, Agus Pujianto ${ }^{2}$, Mohamad Annas ${ }^{3}$ \\ \{hermawan_pamot@mail.unnes.ac.id ${ }^{1}$, guspujianto.73@mail.unnes.ac.id ${ }^{2}$, \\ 3syakhustiani@mail.unnes.ac.id ${ }^{3}$ \} \\ Universitas Negeri Semarang, Semarang, Indonesia ${ }^{1,2,3}$
}

\begin{abstract}
This study aims to develop a model of physical education and sports learning. Development was carried out on physical education learning of non-locomotor archetype materials in elementary school using Teaching Personal And Social Responsibility approach. This research method uses Research and Development Approach. The research consisting of five main stages, were: 1) Needs Analysis, 2) Product Planning and Design Learning Model, 3) Expert validation, 4) Field trials, 5) Product Revision. The results of the needs analysis show that teachers and students need improvised learning materials of non-locomotor basic motion materials. The recommendations need to develop a model of physical education and sports learning for lower graders in elementary school. The average expert rating of $89.73 \%$ falls under the category "Excellent". The developing a model of physical education and sports learning, of non-locomotor archetype materials in elementary school using Teaching Personal And Social Responsibility approach, shows the students were able to explore non-locomotor motion skills in train games. The value of non-locomotor attitudes, knowledge and movement skills has increased.
\end{abstract}

Keywords: Model, Learning, Motion, Basic, Non Locomotor, Physical.

\section{Introduction}

There is evidence to suggest that basic movement skills of children aged four to seven years and weak physical activity are related (Smith, 2014). More specifically, research shows that the motor skills of children affect the physical activity and fitness of adolescents. Therefore, the ability to perform various Fundamental Movement Skills (FMS) increases the likelihood of a child participating in different physical activities throughout their life. Furthermore, sufficient fundamental movement skills are considered to be one of the most important antecedents of physical activity and can facilitate participation and success in many sports and sports activities undertaken during school and leisure.

Several studies have shown that childhood and adolescence are crucial periods in the adoption of an active physical lifestyle since the level of physical activity adopted in childhood (Friedman et al. 2008; Telama et al. 2005; Trudeau, Laurencelle, and Shephard 2004). Several other studies, however, have shown that physical activity usually decreases during puberty. The decline in levels of physical involvement is very steep during junior high 
school (ie, between the ages of 13 and 15) (Nader, Bradley, and Houts 2008; Telama and Yang 2000). These findings have led researchers to investigate possible antecedents of physical activity participation during childhood and adolescence.

Fundamental Movement Skills(FMS) consists of locomotor, manipulative, and balance skills. Locomotor skills refer to the body moving from one point to another in vertical or horizontal dimensions. Activities, such as walking, running, jumping, jumping, skipping, running, sliding, jumping, and climbing are examples of locomotor movement skills (Gallahue and Cleland-Donnelly 2007). Manipulative skills include gross motor movement or fine motor movement. Gross motor manipulative skills involve movements that provide power to objects or receive forces from objects. Throwing, catching, kicking, trapping, striking, volleying, bouncing, rolling, and punting are examples of basic gross motor manipulative skills. Fine motor manipulative skills refer to the activities of handling small objects that emphasize motor control, precision and accuracy of movement. Equilibrium refers to both bodies remaining in place but moving around a horizontal or vertical axis (Gallahue and Cleland-Donnelly 2007) and processes for maintaining postural stability (Westcott, Lowes, and Richardson 1997). More specifically, Westcott, Lowes, and Richardson defined static balance as' the ability to maintain posture, such as balancing a standing or sitting position ', and dynamic balance as' the ability to maintain postural control during other movements, such as reaching an object or walking across a yard. grass. According to Gallahue and Cleland-Donnelly (2007), axial movements, such as bending, Westcott, Lowes, and Richardson defined static balance as' the ability to maintain posture, such as balancing a standing or sitting position ', and dynamic balance as' the ability to maintain postural control during other movements, such as reaching an object or walking across a yard. grass. According to Gallahue and Cleland-Donnelly (2007), axial movements, such as bending, Westcott, Lowes, and Richardson defined static balance as' the ability to maintain posture, such as balancing a standing or sitting position ', and dynamic balance as' the ability to maintain postural control during other movements, such as reaching an object or walking across a yard. grass. According to Gallahue and ClelandDonnelly (2007), axial movements, such as bending,

In the motor learning literature there are two hypotheses that describe skill acquisition. One of them is transfer, which implies the influence of previous practice or skill performance or skills on the learning of new skills (Magill 2007). Another one is called the specificity hypothesis which suggests that the ability is specific to the task or purpose of the activity and cannot be transferred (Henry 1958). According to O'Keeffe, Harrison, and Smyth (2007), researchers have typically applied either transfer or specificity hypotheses as theoretical frameworks for the study of motor learning and only a few studies have utilized both perspectives simultaneously. Therefore, this hypothesis is somewhat contradictory in motor learning research and has created debate among scientists. Other findings from O 'Keeffe, Harrison, and Smyth (2007) argue that there is not much empirical evidence on either of the two hypotheses in practical learning / teaching situations. This suggests that the conclusions made by many practitioners when choosing learning and teaching methods may not have a solid scientific basis. O'Keeffe, Harrison, and Smyth (2007) also found that few researchers have attempted to combine the transfer and specificity hypotheses (Cratty 1966; Sharp 1992). According to this assumption, beginners can use basic motor skills with some degree of success. However, when a learner adopts more skills, the techniques become more distinctive and the practice must be specific. and Smyth (2007) argue that there is not much empirical evidence on either of the two hypotheses in practical learning / teaching situations. This suggests that the conclusions made by many practitioners when choosing learning and teaching methods may not have a solid scientific basis. O'Keeffe, Harrison, and Smyth (2007) 
also found that few researchers have attempted to combine the transfer and specificity hypotheses (Cratty 1966; Sharp 1992). According to this assumption, beginners can use basic motor skills with some degree of success. However, when a learner adopts more skills, the techniques become more distinctive and the practice must be specific. and Smyth (2007) argue that there is not much empirical evidence on either of the two hypotheses in practical learning / teaching situations. This suggests that the conclusions made by many practitioners when choosing learning and teaching methods may not have a solid scientific basis. O'Keeffe, Harrison, and Smyth (2007) also found that few researchers have attempted to combine the transfer and specificity hypotheses (Cratty 1966; Sharp 1992). According to this assumption, beginners can use basic motor skills with some degree of success. However, when a learner adopts more skills, the techniques become more distinctive and the practice must be specific. This suggests that the conclusions made by many practitioners when choosing learning and teaching methods may not have a solid scientific basis. O'Keeffe, Harrison, and Smyth (2007) also found that few researchers have attempted to combine the transfer and specificity hypotheses (Cratty 1966; Sharp 1992). According to this assumption, beginners can use basic motor skills with some degree of success. However, when a learner adopts more skills, the techniques become more distinctive and the practice must be specific. This suggests that the conclusions made by many practitioners when choosing learning and teaching methods may not have a solid scientific basis. O'Keeffe, Harrison, and Smyth (2007) also found that few researchers have attempted to combine the transfer and specificity hypotheses (Cratty 1966; Sharp 1992). According to this assumption, beginners can use basic motor skills with some degree of success. However, when a learner adopts more skills, the techniques become more distinctive and the practice must be specific. According to this assumption, beginners can use basic motor skills with some degree of success. However, when a learner adopts more skills, the techniques become more distinctive and the practice must be specific. According to this assumption, beginners can use basic motor skills with some degree of success. However, when a learner adopts more skills, the techniques become more distinctive and the practice must be specific.

Motion learning must be taught from an early age. Human life is shaped by the capacity for skillful movement. Some movement skills make life possible. Without essential movement skills, we cannot protect ourselves from the dangers of our environment, build shelters, provide food, move from one place to another, or reproduce. (William H Edward, 2010). Some of the research results found that: In the implementation of basic movement education in elementary schools, there are many obstacles and obstacles, including limited facilities and infrastructure at school, the result is low basic movement skills of children(Agustini, Tomi, \& Sudjana, 2016; Ayu Septiani, Sri Hanani Department of Physical Education, Health and Recreation, \& Sport Science, 2016; Hidayat, 2017). In addition, the results of other research on basic motion learning found that the basic movement abilities of students who were treated with Game Series Learning Strategies (SPRP) were better than students who were taught with Conventional Learning Strategies (SPK). The results of the conclusions about the students' basic motor skills concluded that the basic movement abilities of school students in cities were better than those in the suburbs(Bakhtiar, 2014).

Learning development in this research, Researchers will develop basic motion material with the TPSR model (Teaching Personal And Social Responsiveness) into the lower class learning process. This TPSR model has a strong foundation in humanism to create a studentcentered approach with the aim of facilitating the development of student personal and social responsibility. The uniqueness of this model lies in its focus on setting goals for student participation in class. Another important aspect of this model is to encourage students to be 
more reflective in decision making and to provide access for students to express their opinions, interests, and feelings. The aim is for students to be able to model appropriate choices of behavior and activities through this type of teaching, and will show a greater concern for the well-being, safety, and quality of their peers' experiences. (Clocksin, Wattson, Williams, \& Randsell, 2009; D. Watson \& Clocksin, 2013; DL Watson \& Clocksin, 2011). If it can be implemented properly, this program will be able to form an attitude of personal responsibility and social responsibility of the participants, and the role of the instructor / teacher also plays an important role in creating such a situation, so that this TPSR model can be integrated into the learning program in schools.

\section{Method}

Research design. This study uses Research and Development research which is used to develop or validate products used in learning education. Furthermore, it is stated that the research and development procedure basically consists of two main objectives, namely: (1) product development, and (2) testing the effectiveness of the product in achieving the goal. This development model is descriptive of development, because the procedure used describes the steps that must be followed, and is used to find a model or prototype, and can be used for learning (Arikunto, 2006). According toDwiyogo (2016) in each development can choose and find the most appropriate steps for their research based on the conditions and constraints faced.

Research procedure. Based on some of the opinions above, the procedure used in the development of the basic movement pattern learning model for the lower classes of Elementary Schools through the TPSR approach consists of five main stages, namely:

\section{Needs Analysis}

Conducted visits to elementary schools (SD Patemon 01, SD Patemon 02, SD Sekaran 02, SD Sukorejo 02, SD Sampangan 01, SD Srondol Kulon 02) to make direct observations by analyzing teacher books and student books related to the content of class locomotor basic motion patterns 1 in accordance with the demands of KD in the 2013 curriculum.

The follow-up action was to conduct FGDs with 20 Primary School Physical Education Teachers in several cities in Central Java (Semarang City. Pemalang Regency, Brebes City, Pati Regency, Tegal City, Wonosobo Regency, Kendal Regency).

Literature analysis from books and previous research (books $\&$ journals)

Visiting Elementary Schools (SD Sukorejo 02, SD Sampangan 01, SD Srondol Kulon 02) to analyze the Physical Education learning process related to the use of teaching approaches and methods in grade 1 schools.

Planning and Designing Learning Model Products

The results of the above needs analysis then the researcher designed the basic locomotor motion learning model for class 1 . With the steps as follows:

Initial observations at SDN 01 Sukorejo, SDN Patemon 01 and 02, SDN Sekaran 01 and 02, SDN 01 Sampangan and SDN 02 Srondol Kulon, to determine the movement characteristics of grade 1 students, to know the game material that has been taught and to know the condition of the area of the school environment to design the shape the field that will be used to play. 
Analysis of the character of attitudes in students grade 1 and the result is that in general they are not accustomed to having a responsible attitude towards assignments, not accustomed to respecting and caring for others, not accustomed to respecting others

Game technical analysisnamely: a. Purpose of play, b. The various roles to be played, c. Characteristics of motion in play, d. Game rules, e. Determine how to play, f. Sarpras to be used in playing, g. Assesses the principles or ways of developing a game.

Expert validation

The initial product of developing a basic motion learning model using the TPSR approach, before being tested in a small-scale test, it is validated by experts in accordance with this field of research. To validate the product to be produced, the researcher involved 4 (four) experts from lecturers and professional teachers. The product design was evaluated by 4 experts with different competencies, namely 1. Mr. Donny Wirayudha K. Ph.d as a game expert, 2, Mr. Supardi SPd. M. Or as a game expert, 3. Mr Slamet Mokhamed SPd as a Learning expert, 4. Mr Krismunadi SPd as a learning expert.

Field Trial

Small Scale Trial conducted in Sukorejo 02 State Elementary School with the research subjects were all 24 students of grade 1

Large Group Trials, conducted at the Sampangan 01 Elementary School with the research subjects were all students in grade 1 totaling 28 students

Feasibility Trial, conducted at the Srondol Kulon 02 Elementary School with the research subjects were all grade 1 students totaling 28 students

Data collection technique

The instrument uses a questionnaire for learning experts and game experts, attitude value observation sheets, knowledge value observation sheets and skill value observation sheets for field trials.

\section{Product Revisions}

The revision of the product model for the low-class basic locomotor motion pattern was carried out based on input from experts, as well as trial results. to repair the product before the end product is used.

Data Sources and Research Subjects.

The data source of this research came from information on the Physical Education Teachers at SD Patemon 01 and 02, SD around 02, 10 SD in Gunungpati district and 10 SD outside Semarang City, 4 game experts and learning experts. The subjects of this study were all students of SD Negeri Sukorejo 02 class 1 totaling 24 students from Sampangan 01 Elementary School with 28 students in grade 1, Srondol Kulon 02 Elementary School with 28 students in grade 1.

\section{Data Collection Techniques and Instruments}

The instrument used in the development of the learning model, in the form of an observation guide. Observation is used to find out about the efficiency and effectiveness of learning models about improving student attitudes, knowledge and skills as well as expert opinion. Assessment is used to obtain information in the form of a nominative assessment of the model product to be produced. In this study, the instrument used to collect data on children's learning outcomes was an assessment of children's learning outcomes in one learning process in one meeting. Instrument validation for physical education learning models (Donny, 2015).

Data analysis technique

The test result data will be analyzed in a descriptive analytic manner, by carrying out an in-depth study and analysis of the information and / or feedback that can be captured from the 
test subjects. The product of this learning model will be said to be successful if it can be used as a learning model in schools and is able to complete student learning outcomes in accordance with the learning objectives.

\section{Result and Discussion}

Needs Analysis. The results of the discussion with the teachers, in the FGD, about the implementation of the learning process in schools that have been carried out so far are: 1 . There is a need for improvisation of the process related to learning material for locomotor basic motion. 2 . There was confusion in the implementation in the field, even though they had followed the Bintek. 3. Teachers teach based only on the experience they have. For the minutes of this discussion, it is necessary to develop a learning model for basic movement patterns for grade 1 in elementary schools. The results of the FGD can be seen in table 1 below:

Table 1. Results of Class 1 Teacher Book Analysis

\begin{tabular}{|c|c|c|c|c|}
\hline Teacher's Book Material Content & Complete & $\begin{array}{l}\text { Less } \\
\text { complete }\end{array}$ & Incomplete & Nothing \\
\hline $\begin{array}{l}\text { The content of the book material is related to } \\
\text { religious attitudes (living and practicing the } \\
\text { religion they adhere to) and social attitudes }\end{array}$ & & & 20 & \\
\hline $\begin{array}{l}\text { The content of social education materials related } \\
\text { to the formation of children's character, for } \\
\text { example: discipline, independence, cooperation, } \\
\text { respect for others and so on }\end{array}$ & & & 4 & 16 \\
\hline Locomotor basic motion material content & & 16 & 4 & \\
\hline $\begin{array}{l}\text { The suitability of the material with the } \\
\text { development of students }\end{array}$ & & 14 & 6 & \\
\hline
\end{tabular}

\subsection{Planning and Design of Class Learning Model Products 1}

From the results of the observation data obtained, it is concluded that the traditional game "Ride the Train" is considered appropriate and effective to use for Learning Model research, there are objectives, kinds of roles, characters, provisions and regulations as stated in the technical analysis above. Overall, the reason is that the traditional game "Ride the Train" is in accordance with the school conditions and situation. 


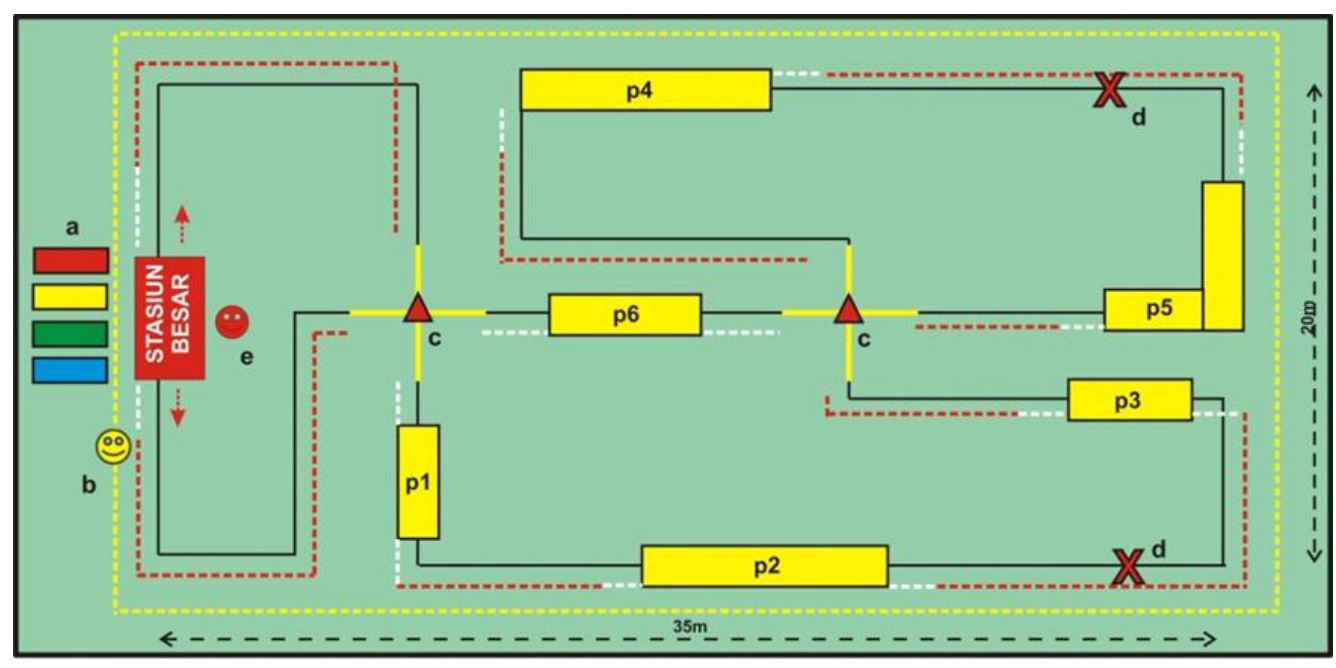

\section{Legends:}

$\mathrm{a}=$ train carriage

$\mathrm{b}=$ station master

$\mathrm{c}=$ traffic controller

$\mathrm{d}=$ latch

$\mathrm{e}=$ supervisory officer

white line $=$ road

red line $=$ run

yellow line intersection $=$ railroad crossing line yellow line $=$ station master route,

p1 = jump crank obstacle post,

p2 $=$ straight bridge obstacle post,

p3 = hurdle jump post,

p4 = oblique bridge obstacle post,

p5 $=$ the train obstacle post backward,

p6 $=$ rail barrier post is damaged

Movements made in accordance with the level of development and growth of grade 1 elementary school children and in accordance with the demands of KD at the 2013 Kurikulum, namely:

Table 2. Basic Motion of Class 1 Locomotor

\begin{tabular}{|c|c|c|}
\hline Movement Type & Movement Purpose & Attitude Built \\
\hline $\begin{array}{l}\text { Play train: } \\
\text { 1. Walk straight, walk turns, } \\
\text { walk sideways and walk } \\
\text { backward } \\
\text { 2. Running straight, running } \\
\text { turns, running sideways } \\
\text { and running backwards } \\
\text { 3. Jump / crank your legs, } \\
\text { turn straight and jump } \\
\text { sideways. } \\
\text { 4umping two straight legs, } \\
\text { jumping sideways. } \\
\text { This game can be varied with } \\
\text { various movements and } \\
\text { adapted to the basic } \\
\text { competencies of grade } 1 \text { SD. }\end{array}$ & $\begin{array}{l}\text { To build students' } \\
\text { physical fitness by } \\
\text { exploring qualities: } \\
\text { 1. Motion agility. } \\
\text { 2. Movement speed. } \\
\text { 3. Endurance of } \\
\text { motion } \\
\text { 4. Muscle strength } \\
\text { 5. Flexibility of } \\
\text { motion. }\end{array}$ & $\begin{array}{l}\text { In playing, it involves all students to play a } \\
\text { role in accordance with their duties, both } \\
\text { individually and in groups, so that it will } \\
\text { foster attitudes: } \\
\text { 1. Responsibility for yourself and others. } \\
\text { 2. Participation and self-control. } \\
\text { 3. Respect for others } \\
\text { 4. Cooperating between friends without } \\
\text { 5. Capervision } \\
\text { 5. help / sacrifice for others. }\end{array}$ \\
\hline
\end{tabular}




\subsection{Expert Validation}

Experts agree to provide some suggestions and revisions to the design of game products as follows: 1) The shape of the field should not have many turns making it difficult for students to play, so it is advisable to make simple forms such as regular square-shaped fields so that students can easily remember them;2) The number of obstacles that must be passed is large, so it is recommended to reduce the number. The product revision results are as shown in the following figure.

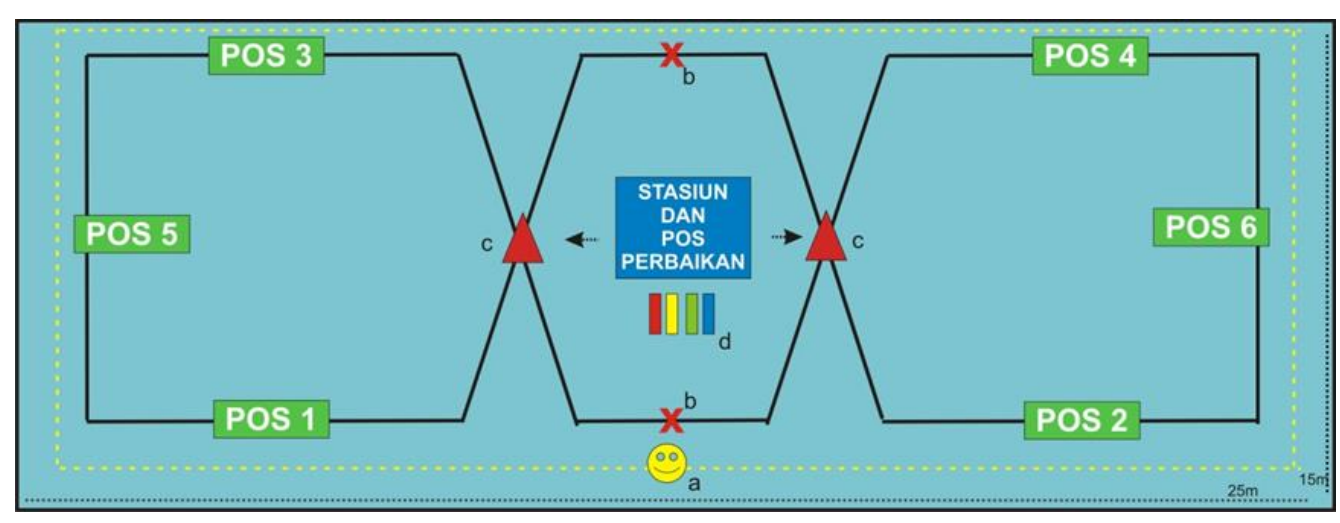

\section{Legends:}

\begin{tabular}{|l|l}
\hline $\mathrm{a}=$ station master & $\mathrm{p} 2=$ straight bridge obstacle post \\
$\mathrm{b}=$ latch & $\mathrm{p} 3=$ hurdle jump post \\
$\mathrm{c}=$ traffic controller & p4 = oblique bridge obstacle post \\
$\mathrm{d}=$ train & p5 = reverse train obstacle post \\
yellow line (stationmaster route) & p6 = rail barrier post is damaged \\
p1 = jump crank obstacle post & \\
\hline
\end{tabular}

Movements made in accordance with the level of development and growth of grade 1 elementary school children and in accordance with the demands of KD in the 2013 curriculum, namely:

Table 3. Basic Motion of Class 1 Locomotor

\begin{tabular}{|c|c|c|}
\hline Movement Type & Movement Purpose & Attitude Built \\
\hline Play train: & To build & In playing, it involves all students to \\
\hline 1. Walk straight, walk turns, walk & physical fitness by & play a role in accordance with their \\
\hline sideways and walk backward & exploring qualities: & duties, both individually and in \\
\hline $\begin{array}{l}\text { 2. Running straight, running } \\
\text { turns, running sideways and }\end{array}$ & $\begin{array}{l}\text { 1. Motion agility. } \\
\text { 2. Movement speed. }\end{array}$ & $\begin{array}{l}\text { groups, so that it will foster } \\
\text { attitudes: }\end{array}$ \\
\hline running backwards & 3. Endurance & 1. Responsibility for yourself and \\
\hline $\begin{array}{l}\text { 3. Jump / crank your legs, turn } \\
\text { straight and jump sideways. }\end{array}$ & $\begin{array}{ll} & \text { motion } \\
\text { 4. } & \text { Muscle strength }\end{array}$ & $\begin{array}{l}\text { others. } \\
\text { 2. Participation and self-control. }\end{array}$ \\
\hline jumping sideways. & & 4. Cooperating between friends \\
\hline $\begin{array}{l}\text { This game can be varied with various } \\
\text { movements and adapted to the basic } \\
\text { competencies of grade } 1 \text { SD. }\end{array}$ & & $\begin{array}{l}\text { without supervision } \\
\text { 5. Care / help / sacrifice for } \\
\text { others. }\end{array}$ \\
\hline
\end{tabular}




\subsection{Field Trial}

\section{Small Scale Trial Results}

Attitude Assessment (TPSR). The results of increasing the attitude value in the small-scale test learning process are presented in the table as follows:

Table 4. Results of Attitude Improvement

\begin{tabular}{clcc}
\hline No. & \multicolumn{1}{c}{ Information } & $\begin{array}{c}\text { Observation } \\
\text { results }\end{array}$ & $\begin{array}{c}\text { The results of the small scale test } \\
\text { attitude value }\end{array}$ \\
\hline $\mathbf{1}$ & Level 0 Irresponsibility & 1 & 1 \\
\hline $\mathbf{2}$ & Level 1 Respect Numbered & 10 & 6 \\
\hline $\mathbf{3}$ & $\begin{array}{l}\text { Level 2 Attitude of } \\
\text { Participation }\end{array}$ & 12 & 9 \\
\hline $\mathbf{4}$ & Level 3 Self-Direction & 1 & 7 \\
\hline $\mathbf{5}$ & Level 4 Caring & 0 & 1 \\
\hline
\end{tabular}

The results of the attitude assessment show that there is an increase in the attitude character score at level 1, 2, 3, 4, but at level 0 it does not increase. Based on the data above, it can be concluded that this game is able to explore the ability of attitudes in grade 1 elementary school students. The data above can be presented in the form of the following diagram.

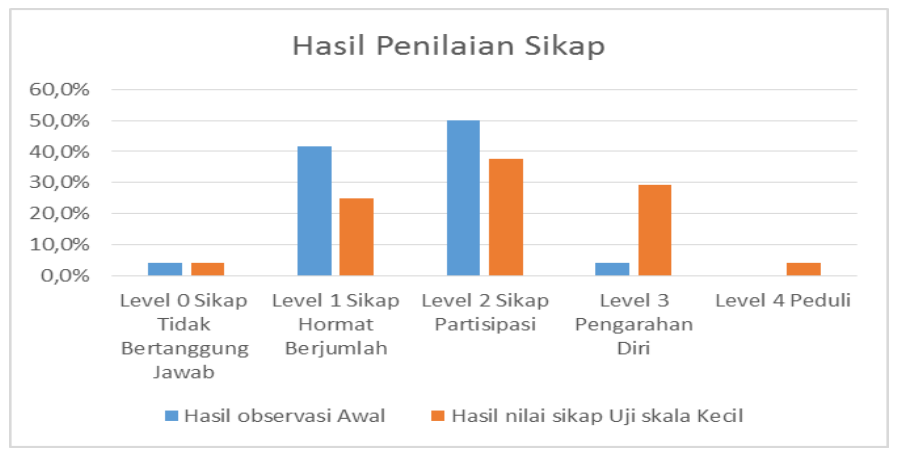

Knowledge Outcome Assessment. The graph of the results of the assessment is as follows:

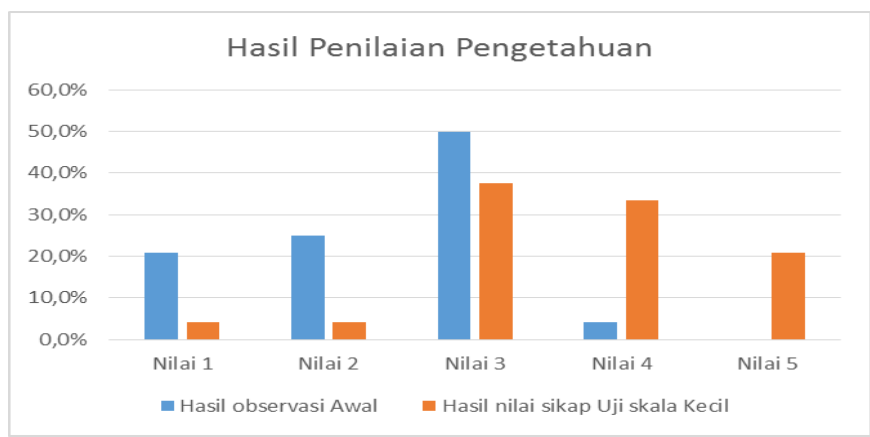

Fig. 3. Value of Knowledge Results 
The results of the knowledge assessment show that all students are able to get scores with the distribution as above, so it can be concluded that this game is able to explore students 'knowledge abilities and is able to explore students' courage to dare to speak in front of friends and teachers.

Skills assessment. The graph of the results of the assessment is as follows:

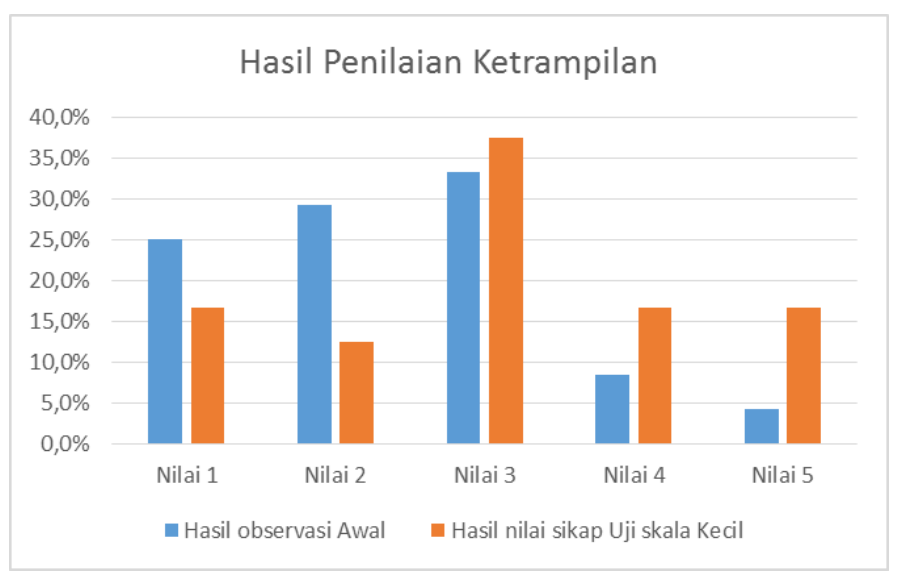

Fig. 4. Results of Skills Value.

The results of the skills assessment show that all students are able to get the scores with the distribution as above, so it can be concluded that this game is able to explore the students' locomotor ability.

\section{Large Scale Trial Results}

Attitude Assessment (TPSR). The observation results obtained initial attitude data as follows:

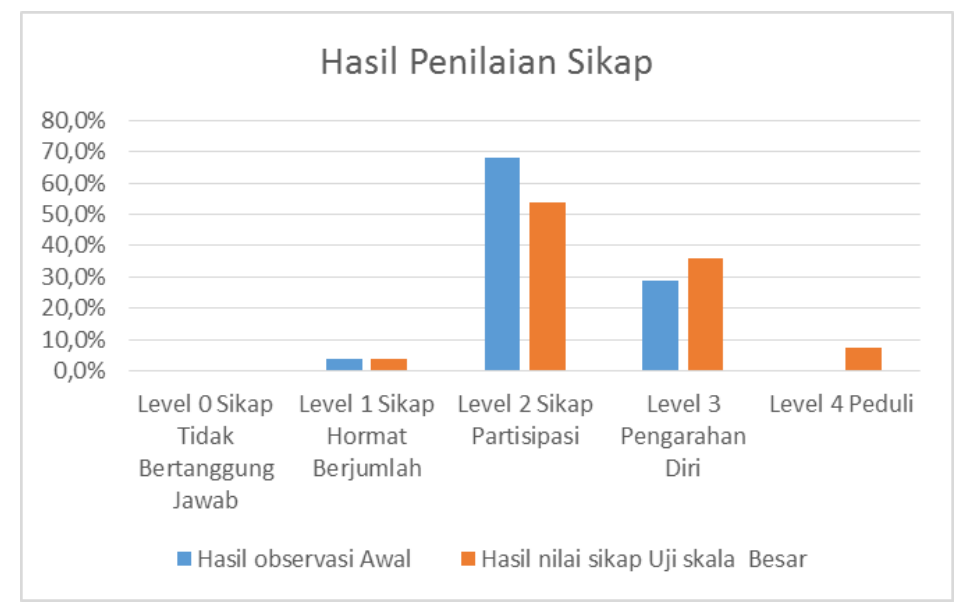

Fig. 6. The Value of the Attitude of the Large Scale Test 
The results of increasing the attitude value in the large-scale test learning process are presented in the table as follows:

Table 5. Results of Attitude Improvement

\begin{tabular}{clcc}
\hline No. & \multicolumn{1}{c}{ Information } & $\begin{array}{c}\text { Observation } \\
\text { results }\end{array}$ & $\begin{array}{c}\text { The results of the attitude value test on } \\
\text { a large scale }\end{array}$ \\
\hline $\mathbf{1}$ & Level 0 Irresponsibility & 0 & 0 \\
\hline $\mathbf{2}$ & Level 1 Respect Numbered & 1 & 1 \\
\hline $\mathbf{3}$ & $\begin{array}{l}\text { Level 2 Attitude of } \\
\text { Participation }\end{array}$ & 19 & 15 \\
\hline $\mathbf{4}$ & Level 3 Self-Direction & 8 & 10 \\
\hline $\mathbf{5}$ & Level 4 Caring & 0 & 2 \\
\hline
\end{tabular}

The results of the attitude assessment show that there is an increase in the attitude character score at levels 1, 2, 3, 4. Based on the data above, it can be concluded that this game is able to explore the attitude abilities of grade 1 elementary school students.

Knowledge Assessment. The graph of the results of the assessment is as follows:

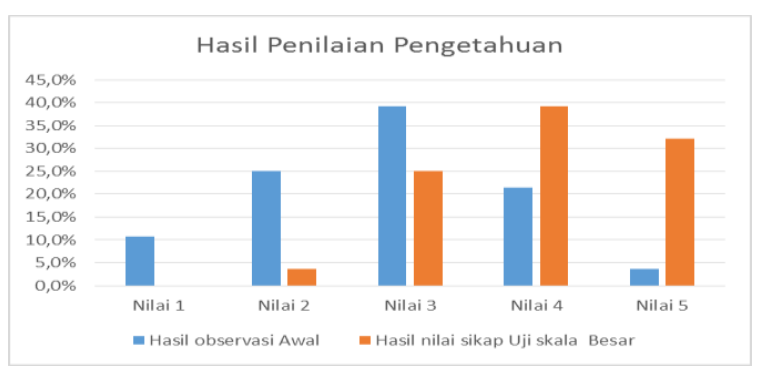

Fig. 7. Value of Knowledge Results

The results of the knowledge assessment show that all students are able to get scores with the distribution as above, so it can be concluded that this game is able to explore students 'knowledge abilities and is able to explore students' courage to dare to speak in front of friends and teachers.

Skills Assessment. The graph of the results of the assessment is as follows:

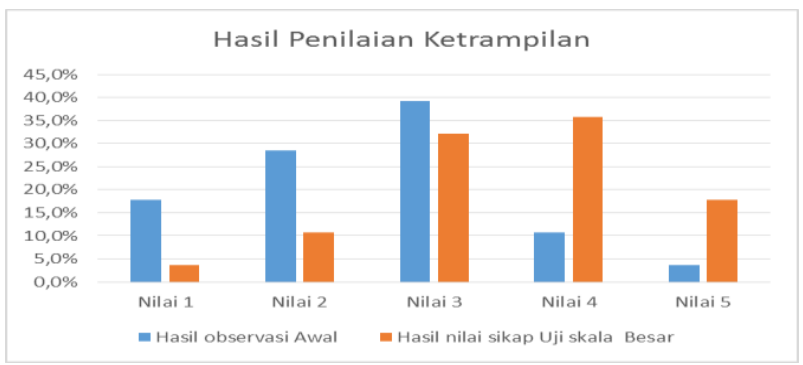

Fig. 8. Value of Skills Results. 
The results of the skills assessment show that all students are able to get the scores with the distribution as above, so it can be concluded that this game is able to explore the students' locomotor ability.

\section{Feasibility Test Results}

Attitude Assessment (TPSR). The results of increasing the attitude value in the feasibility test learning process are presented in the table as follows:

\begin{tabular}{clcc}
\hline No. & \multicolumn{1}{c}{ Information } & $\begin{array}{c}\text { Observation } \\
\text { results }\end{array}$ & $\begin{array}{c}\text { The results of the attitude value test on } \\
\text { a large scale }\end{array}$ \\
\hline $\mathbf{1}$ & Level 0 Irresponsibility & 0 & 0 \\
\hline $\mathbf{2}$ & Level 1 Respect Numbered & 0 & 0 \\
\hline $\mathbf{3}$ & $\begin{array}{l}\text { Level 2 Attitude of } \\
\text { Participation }\end{array}$ & 16 & 7 \\
\hline $\mathbf{4}$ & Level 3 Self-Direction & 10 & 14 \\
\hline $\mathbf{5}$ & Level 4 Caring & 2 & 7 \\
\hline
\end{tabular}

As in the table above, the following diagram can be presented

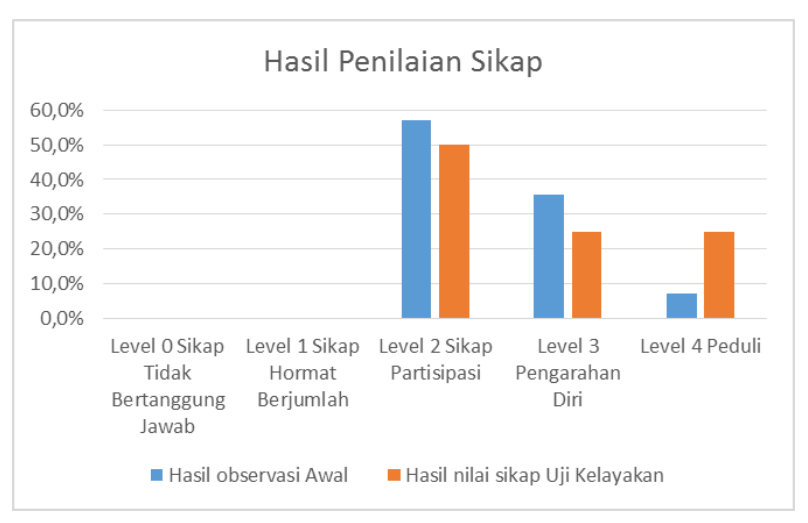

Fig. 9. Attitude Value

The results of the attitude assessment show that there is an increase in the attitude character score at levels 2,3,4. So it can be concluded that this game is able to explore the attitude abilities of grade 1 elementary school students.

Knowledge Assessment. The graph of the results of the assessment is as follows: 


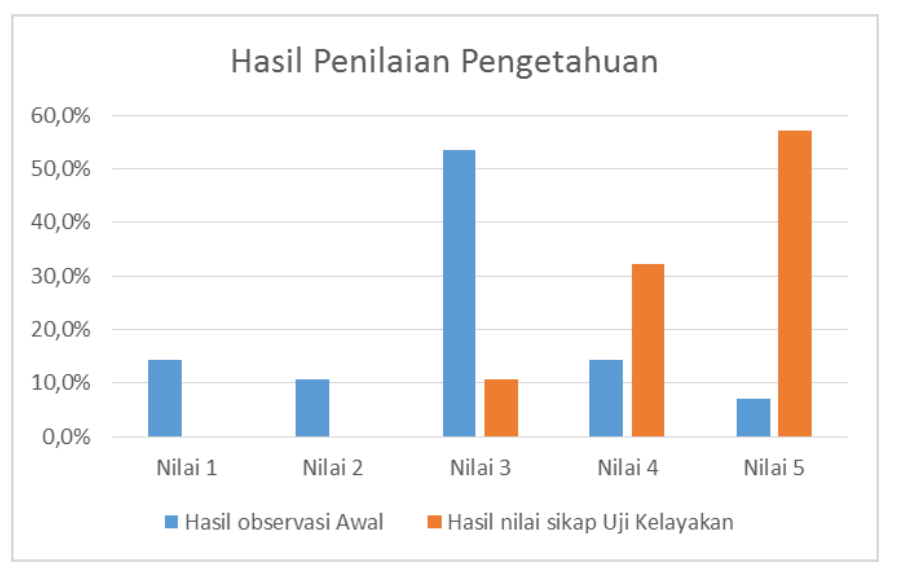

Fig. 11. Value of Knowledge Results

The results of the knowledge assessment show that all students are able to get scores with the distribution as above, so it can be concluded that this game is able to explore students 'knowledge abilities and is able to explore students' courage to dare to speak in front of friends and teachers.

Skills Assessment. The graph of the results of the assessment is as follows:

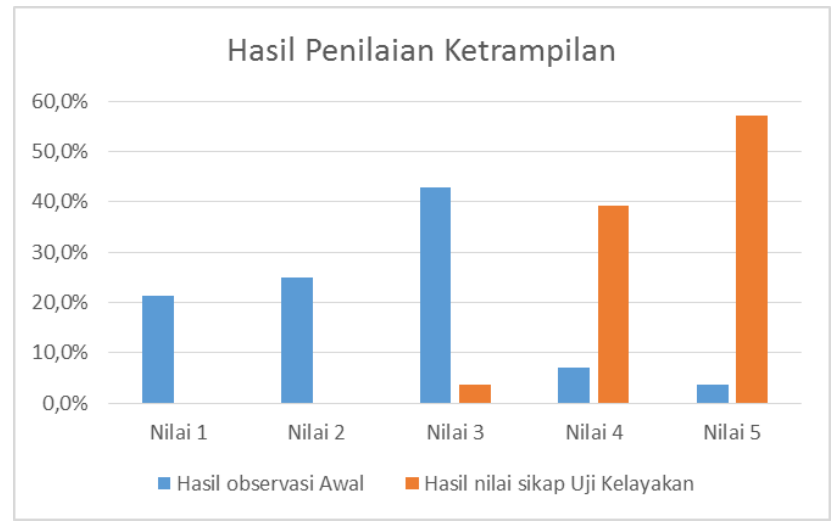

Fig. 12. Values of Skills Results.

The results of the skills assessment show that all students are able to get the scores with the distribution as above, so it can be concluded that this game is able to explore the students' locomotor ability. 


\section{Conclusion}

Based on the research results, 1) Needs Analysis: 1. There needs to be an improvisation of the learning material process for locomotor basic motion. 2. There were difficulties in implementing it in the field, even though it had followed the Bintek. 3. Teachers teach based on experience only. The resulting recommendations need to develop a learning model for basic movement patterns for grade 1 in elementary schools. 2) Planning and Design of Learning Model Products: A design that develops a design of field shapes and sizes that is appropriate and effective in accordance with the characteristics of the environmental conditions of lower class elementary school students. 3) Expert validation: The average result of the overall expert judgment is $89.73 \%$ and this percentage is included in the "Very Good" category. 4) Field trials: The field trials assessed include: a) attitude value in the learning process; there is an increase, but level 0 has not increased; b) Assessment of Knowledge Results: the game is able to explore students 'knowledge and courage skills, c) Skills assessment: the game is able to explore students' locomotor movement abilities.5) Product Revision: Based on the evaluation of game experts and game learning experts, it can be used for physical education learning material for basic locomotor motion patterns for lower classes of elementary school. The developing a model of physical education and sports learning, of non-locomotor archetype materials in elementary school using Teaching Personal And Social Responsibility approach, shows the students were able to explore non-locomotor motion skills in train games. The value of non-locomotor attitudes, knowledge and movement skills has increased.

\section{References}

[1] Agustini., Ikee Proklamasi, Agus Tomi dan I Nengah Sudjana. (2016). Peningkatan Keterampilan Gerak Dasar Lokomotor Menggunakan Metode Bermain Dalam Pembelajaran Pendidikan Jasmani Siswa Kelas III C SDN Krian 3 Kabupaten Sidoarjo (Skills Enhancement of Locomotor Basic Motion using Game Methods in Learning Education Physical Class III C SDN Krian 3 Sidoarjo Residence). Jurnal Pendidikan Jasmani (Education Physical Journal), Volume $26^{\text {th }}$, Nomor $02^{\text {rd }}$. Halaman $229-237$

[2] Arikunto, Suharsimi. (2006). Prosedur Penelitian : Suatu Pendekatan Praktik (Research Procedure: A Practical Approach), Edisi. Revisi $4^{\text {th }}$, Jakarta : PT Rineka Cipta

[3] Clocksin, B. D., Wattson, D. L., Williams, D. P., \& Randsell, L. (2009). Integrated Health and Physical Education Program to Reduce Media Use and Increase Physical Activity in Youth.Physical Educator.

[4] Cratty, B.J. (1966). A Three-Level Theory Of Perceptual Motor Behavior. Quest, May: 3-10 (Monograph VI).

[5] Donny Wira Yudha Kusuma, Hermawan Pamot Raharjo, Mulawarman Sudjito Taathadi. (2015). Introducing a New Agility Test in Badminton. American Journal of Sports Science: $3^{\text {rd }}$ (1): 18 28.

[6] Dwiyogo, Wasis D. (2016). Pembelajaran berbasis blended learning (mdel rancangan pembelaajaran). Malang : Wineka Media.

[7] Edwards., William H. (2010). Motor Learning and Control: From Theory to Practice. Wadsworth: Cengage Learning.

[8] Friedman, H.S., L.R. Martin, J.S. Tucker, M.H. Criqui, M.L. Kern, and C.A. Reynolds. (2008). Stability of physical activity across the lifespan. Journal of Health Psychology 13 ${ }^{\text {rd: }}$ 1092-2006.

[9] Gallahue, D., and F. Cleland-Donnelly. (2007). Developmental physical education for all children. $5^{\text {th }}$ ed. Champaign, IL: Human Kinetics.

[10] Kalaja., Sami Pekka, Timo Tapio Jaakkola, Jarmo Olavi Liukkonen a \& Nikolaos Digelidis. (2012). Development of junior high school students' fundamental movement skills and physical 
activity in a naturalistic physical education setting. Journal Physical Education and Sport Pedagogy. Vol. $17^{\text {th }}$, No. $4^{\text {th }}$, September 2012, 411-428

[11] Magill, Richard. (2007). Motor Learning and Control: Concepts and Applications. New York: McGraw-Hill.

[12] Nader, P.R., R.H. Bradley, and R.M. Houts. (2008). Moderate-to-vigorous physical activity from ages 9 to 15 years. Journal of American Medical Association 300"th: 295-305.

[13] O'Keeffe, S.L., A.J. Harrison, and P.J. Smyth. (2007). Transfer or Specificity? An Applied Investigation Into The Relationship Between Fundamental Overarm Throwing And Related Sport Skills. Physical Education and Sport Pedagogy 12 $2^{\text {nd }}: 89-102$.

[14] Septiani, Mita Ayu., dan Endang Sri Hanani. (2016). Pengembangan Pembelajaran Bola Basket melalui Permainan Lomba Jaring (Development of Basketball Learning Through The Net Competition Games). Journal of Physical Education, Sport, Health and Recreation ( $\left.2^{\text {nd }}\right)$

[15] Sharp, R. (1992). Acquiring skill in sport. Cheltenham, ON: Sport Dynamics.

[16] Smith., Wayne. (2014). Fundamental movement skills and fundamental games skills are complementary pairs and should be taught in complementary ways at all stages of skill development. Journal Sport, Education and Society Volume $21^{\text {st }}, 2016$ - Issue $3^{\text {rd }}$

[17] Telama, R., and X. Yang. (2000). Decline of physical activity from youth to young adulthood in Finland. Medicine and Science in Sports and Exercise 32 h. 1617-22.

[18] Telama, R., X. Yang, J. Viikari, I. Va“lima“ki, O. Wanne, and O. Raitakari. (2005). Physical activity from childhood to adulthood: A 21-year tracking study. American Journal of Preventive Medicine $3^{\text {rd }}: 267-73$.

[19] Trudeau, F., L. Laurencelle, and R.J. Shephard. 2004. Tracking of physical activity from childhood to adulthood. Journal Medicine and Science in Sports and Exercise 36 ${ }^{\text {th: }}$ 1937-43.

[20] Watson, D. L., \& Clocksin, B. D. (2011). Process is Everything! Enhancing Student Learning in Adventure Education.Strategies (08924562)

[21] Watson, D., \& Clocksin, B. (2013). Using Physical Activity and Sport to Teach Personal and Social Responsibility

[22] Westcott, S.L., L.P. Lowes, and P.K. Richardson. (1997). Evaluation of postural stability in children: Current theories and assessment tools. Physical Therapy $77^{\text {th: }}$ 629-45. 